\title{
PENTINGNYA ASPEK GOVERMENT POWER DALAM PENGEMBANGAN INDUSTRI PARIWISATA DAERAH
}

\author{
Irany Windhyastiti ${ }^{{ }^{*}}$, Diah Widiawati ${ }^{1}$ \\ ${ }^{1}$ Fakultas Ekonomi dan Bisnis Universitas Merdeka Malang \\ *rany_unmermlg@yahoo.co.id
}

\begin{abstract}
:
The tourism industry has the characteristic interdependence : (1) Hospitality Industry (Food and Baverage, and accommodation); (2) Travel (Retail and Wholeseller; The operator); (3) Visitor Services (Attraction; Event; and Tourism Agencies). Therefore, to build a strong tourism industry needed a strong organisational relationships. Power and dependence is an important basic building cooperation between organizations. One of the cities in Indonesia that are prominent in tourism is Kota Batu. Kota Batu is the icon of tourism in East Java. Even in the year 2006-2007, the industry of tourism in Kota Batu had dropped shraply because of overflow of Lapindo mud. In 2012, the total tourists visiting the Kota Batu reached 1,603,441 visitors. In 2013 increased 1,881,446 and 2,089,022 tourists in 2014. That number rises quickly compared in 2007, when the condition of the Kota Batu dropped as the number of tourist visits less than 1 million people. Now, in 2016, The government of Kota Batu target revenue of $R p 1$ trillion, where $80 \%$ is derived from the tourism sector.

Therefore, in the study will be analized how the government power in developing the tourism industry in Kota Batu. The technical analysis of this research uses a combination of analysis statistics and policy analysis. The analysis unit of this study is the tourism industry in Kota Batu. This research population are the stakeholders in the tourism industry: tourism entrepreneur and community. Based on the statistics analysis, the aspect of power has significant influence towards the development of the tourism industry. This shows the importance of the government role in developing the tourism industry.
\end{abstract}

Keywords: Government Power, The Tourism Industry

\section{PENDAHULUAN}

Industri pariwisata memiliki karakteristik saling tergantung satu sama lain (interdependence), yang terbagi dalam tiga jenis yaitu: (1) Hospitality Industry (Food and Baverage, dan Akomodasi); (2) Travel (Retail dan Wholeseller; Operator); (3) Visitor Services (Attraction; Event; dan Tourism Agencies). Oleh karena itu, untuk membangun industri pariwisata yang kuat diperlukan hubungan antar organisasi yang kuat. Hubungan antar organisasi atau yang dikenal dengan business-to business relationship dapat dibangun baik melalui commitment-trust, power-depence dan social capital. Aspek Commitment -trust antar organisasi yang berperan sebagai pelaku wisata diperlukan dalam mewujudkan kerjasama yang baik untuk meciptakan iklim kondusif bagi wisatawan. Sedangkan powerdepence dalam hal ini dilakukan pemerintah dapat dilakukan dengan cara menetapkan kebijakan atau regulasi yang bersifat "memaksa" dengan tujuan untuk mendukung pengembangan sektor industri pariwisata. Selain itu, faktor lain yang tidak kalah penting, adalah social capital, yaitu kemampuan masyarakat untuk ikut berpartisipasi dalam mencapai tujuan dalam hal ini pengembangan sektor pariwisata dimana baik secara langsung maupun tidak langsung seluruh masyarakat dalam suatu daerah nantinya juga akan merasakan manfaat dari dampak berkembangnya industri pariwisata di suatu daerah. 
Salah satu industri pariwisata yang cukup berkembang adalah industri pariwisata di Kota Batu. Kota Batu menjadi salah satu kota tujuan wisata yang cukup diminati di Indonesia. Selain karena udaranya yang sejuk dan pemandangan alamya yang bagus karena terletak di daerah pegunungan, di Kota Batu juga mempunyai berbagai pilihan tempat wisata yang menarik, sehingga menjadikan kota ini menjadi salah satu kota favorit bagi banyak orang untuk berlibur. Wisatawan- wisatawan yang berkunjung ke kota Batu pun tidak hanya wisatawan lokal atau domestik saja melainkan juga wisatawan-wisatawan mancanegara. Pada tahun 2012, total wisatawan yang berkunjung ke Kota Batu mencapai 1.603.441 wisatawan. Pada tahun 2013 meningkat mencapai 1.881 .446 wisatawan dan 2.089.022 wisatawan pada tahun 2014 (Kota Batu Dalam Angka 2015). Angka itu naik drastis jika dibandingkan pada tahun 2007 saat kondisi wisata Kota Batu terpuruk akibat luapan lumpur Lapindo, dimana jumlah kunjungan wisata kurang dari 1 juta orang. Kota Batu bukan hanya menawarkan wisata alam seperti Wisata Cangar, Selekta, Songgoriti dan lain-lain, tetapi Kota Batu juga mempunyai obyek wisata hiburan dan pendidikan yang modern seperti Jatim Park I dan II, Musem Satwa, Batu Secret Zoo, Eco Green Park, Museum Angkut dan lain sebagainya. Kemajuan industri pariwisata Kota Batu memperlihatkan adanya kerjasama yang baik antar berbagai pihak baik itu pengelola usaha wisata maupun masyarakat, bahkan peran pemerintah juga sangat baik dalam mendukung industri pariwisata di Kota Batu.

Saat ini, Kota Batu benar-benar telah mengalami kemajuan pesat. Bahkan pada APBD 2016, Pemkot Batu memasang target pendapatan Rp 1 triliun dimana $80 \%$ berasal dari sektor pariwisata. Oleh karena itu, dalam penelitian ini, akan menggali bagaimana Government Power dari pemerintah dalam peningkatan industri pariwisata di Kota Batu.

\section{KAJIAN PUSTAKA \\ Pemasaran Relasional}

Nilai hubungan jangka panjang merupakan nilai-nilai yang terbangun dan terjalin dari hasil pertukaran relasional antar organisasi yang dikembangkan dengan berbagai entitas (Berry 1983). GrÖnroos (1994) menegaskan bahwa nilai hubungan jangka panjang dicerminkan oleh derajat kesetiaan (loyalitas) pelanggan dan keterlibatan dari pihak-pihak yang berhubungan. Selanjutnya Egan (2001) dan Palmer (1996, 2000) menyatakan bahwa implementasi pemasaran relasional ini akan menghasilkan hubungan kerjasama yang kuat antar organisasi (strong relationship). Didukung pula oleh Hennig-Thurau, et al (2000,2002), bahwa relationship outcomes merupakan hasil-hasil yang bersifat jangka panjang dari pemasaran relasional berupa loyalitas dan komunikasi positif (positive word of mouth communication).

Morgan and Hunt (1994) menegaskan bahwa nilai hubungan jangka panjang yang berkesinambungan akan diperoleh bila dikembangkan perilaku positif antar entitas yang akan mendorong terjalinnya hubungan harmonis diantaranya. Perilaku-perilaku tersebut adalah perilaku yang didasarkan pada perilaku positif, berupa: saling percaya (kepercayaan), komitmen dalam menjalankan hubungan (komitmen relasional) dan kerjasama diberbagai hal secara terus menerus.

Pemasaran relasional (Relationship Marketing) adalah teori, konsep, paradigma, management-pad pemasaran yang berorientasi pada jalinan hubungan harmonis dalam jangka panjang dengan seluruh pemangku kepentingan (Stakeholders) (Berry 1983, Egan 2001, Gummeson 2002, GrÖnroos 1997, Zineldin 1998). Hubungan pemasaran tersebut dapat berupa hubungan antar organisasi maupun hubungan perusahaan dengan konsumen akhir. Beberapa ahli, seperti: Anderson and Weitz (1992), Ghosh, et al (2004), meneliti hubungan antar organisasi yang dikenal sebagai pola business-to-business relationship (pemasok dan manufaktur, 
manufaktur dan distributor, produsen dengan produsen sejenis/ perusahaan sejenis, pedagang besar dengan pengecer, dan antar perusahaan jasa).

Secara teoritik maupun empirik ditegaskan oleh banyak ahli, bahwa keberhasilan hubungan antar organisasi dalam pandangan konsep pemasaran relasional tidak dapat dipisahkan dari pertukaran relasional (relational exchange) para pelaku bisnis yang menjalankannya (Bucklin and Sangupta 1993, Morgan and Hunt 1994, dan Hoffman, 2000).

\section{Kekuatan/Kekuasaan (Power) dalam Kerjasama antar Organisasi}

Definisi dasar dari kekuatan/kekuasaan adalah kemampuan seseorang/ sekelompok orang atau entitas dalam mempengaruhi pihak lain untuk melakukan apa yang diinginkannya (Dahl 1957). Sementara, Emerson (1962) menjelaskan bahwa kekuatan/kekuasaan melekat dalam pertukaran sosial, dan bukanlah atribut dari pelaku pertukaran, karena power akan selalu ada dalam setiap pertukaran sosial. Emerson (1962) menjelaskan bahwa hubungan antar organisasi akan terpelihara dengan baik apabila hasil yang diperoleh dari hubungan tersebut bernilai tinggi dan tidak tersedianya alternatif lain (langka). Sifat dari pertukaran sosial adalah saling terikat (mutual dependence), dan basis dari saling terikat adalah tiap pihak dapat mengontrol atau memengaruhi perilaku/tindakan pihak lain dalam mencapai tujuan bersama/ kesepakatan. Oleh karenanya, definisi kekuatan/kekuasaan dalam konteks hubungan antar entitas organisasi menurut Emerson (1962) adalah kemampuan satu pihak mempengaruhi pihak lain untuk mentaati ketentuan dan atau merubah suatu kondisi yang tidak mendukung keberlangsungan suatu hubungan. Pengertian yang dibangun Emerson (1962) lebih diarahkan pada bagaimana satu pihak dapat mengendalikan pihak lain demi terwujudnya kerjasama yang berkesinambungan, agar pihak yang bekerjasama dapat disiplin, dan taat azas demi mencapai tujuan kerjasama.
Kekuatan/kekuasaan (power) dan ketergantungan (dependency) merupakan dasar penting membangun kerjasama antar organisasi (Hermans \& Shanahan, 2003; Doherthy dan Quinn, 1999; Doherthy dan Alexander, 2006). Power yang menghasilkan suatu yang fantastis/luar biasa adalah coercive power, meskipun dapat pula menuai konflik. Sebagaimana dalam penelitian Alimuddin (2009), yang memposisikan kekuatan/kekuasaan memaksa dan perilakuperilaku positif dalam interaksi relasional sebagai fondasi untuk membangun kerjasama pemasaran yang intens, mencapai nilai-nilai hubungan jangka panjang dan hasil-hasil pemasaran strategis. Dalam penelitian ini, juga menempatkan power dalam ini government power sebagai pengungkit industri pariwisata yang diharapkan dapat menggerakkan semua stakeholders dalam industri pariwisata.

\section{Pariwisata dan Industri Pariwisata}

Dengan semakin berkembangnya pertumbuhan pariwisata di suatu wilayah yang mendorong berbagai kegiatan ekonomi terpusat di dalamnya, secara perlahan dapat menyebabkan terjadinya aglomerasi di daerah perkotaan terutama pusat objek wisata itu sendiri. Pusat perekonomian yang terbentuk inilah kemudian yang dinamakan sebagai pusat pertumbuhan (growth pole), dimana menurut Tarigan (2005) pusat pertumbuhan (growth pole) dapat diartikan dalam dua cara, yaitu secara fungsional dan geografis. Secara fungsional, pusat pertumbuhan adalah suatu lokasi konsentrasi kelompok usaha atau cabang industri yang karena sifat hubungannya memiliki unsurunsur kedinamisan sehingga mampu menstimulasi kehidupan ekonomi baik ke dalam maupun ke luar wilayah. Sementara secara geografis, pusat pertumbuhan adalah suatu lokasi yang banyak memiliki fasilitas dan kemudahan sehingga menjadi pusat daya tarik (pole of attraction).

Seperti yang tercantum dalam UU No.10 Tahun 2009 pengertian tentang wisata diberikan batasan sebagai: "kegiatan perjalanan yang dilakukan oleh seseorang 
atau sekelompok orang dengan mengunjungi tempat tertentu untuk tujuan rekreasi, pengembangan pribadi, atau mempelajari keunikan daya tarik wisata yang dikunjungi dalam jangka waktu sementara". Dalam UU No.10 Tahun 2009 tentang Kepariwisataan dijelaskan tentang definisi pariwisata yaitu, berbagai macam kegiatan wisata dan didukung berbagai fasilitas serta layanan yang disediakan oleh masyarakat, pengusaha, pemerintah dan pemerintah daerah. Sementara Wahab (2003) menerangkan pengertian pariwisata seperti berikut ini: "pariwisata merupakan salah satu bentuk industri baru yang bisa membuka lapangan kerja baru, meningkatkan penghasilan, standar hidup masyararakatnya dengan cepat. Pertumbuhan dan perkembangan sektor pariwisata tidak begitu saja berjalan dan muncul dengan sendirinya. Ada beberapa upaya yang dilakukan pemerintah seperti tambahan dana, perbaikan infrastruktur, peningkatan kualitas sumber daya baik alam maupun manusia. Selain stimulus dari pemerintah diperlukan juga peranan masyarakat yang juga turut mendukung pertumbuhan pariwisata, salah satunya keramahan, penciptaan lingkungan yang bersih, aman dan nyaman. Menurut Yoeti (2008) beberapa faktor yang mendorong pertumbuhan pariwisata antara lain:

a. Three " $T$ " Revolution, yang terdiri dari: (1) Transportation Technology, merupakan bentuk perkembangan teknologi transportasi saat ini yang semakin maju. Dengan pelayanan transportasi yang bagus disertai fasilitas yang lengkap, sehingga tercipta kenyamanan bagi para wisatawan dalam melakukan kunjungan wisata; (2) Telecommunication, dengan munculnya teknologi one touch system yang memberikan kemudahan bagi calon wisatawan dalam memperoleh segala informasi mengenai daerah tujuan wisata yang diinginkannya. Selain sebagai media informasi, one touch system ini menjadi ajang promosi bagi negaranegara yang memiliki daerah tujuan wisata; (3) Tourism \& Travel, dengan adanya kemajuan teknologi transportasi dan telekomunikasi di atas menciptakan mass tourism yang mampu menggerakkan orang-orang ke dalam ruang lingkup global untuk melakukan perjalanan wisata.

b. Hybrid, pada nantinya pariwisata akan mengalami perkembangan melalui berbagai jalan salah satunya adalah pola perjalanan wisata akan mengalami perkembangan dengan sendirinya seperti perjalanan wisata yang diadakan bersama keluarga akan memperpanjang waktu liburannya.

c. Leissure Time, atau waktu senggang yang dimiliki seseorang yang akan mendorong seseorang untuk melakukan perjalanan wisata dalam mengisi waktu luangnya tersebut. Semakin banyak waktu senggang yang dimiliki mungkin saja orang tersebut akan menggunakan waktunya untuk berlibur.

d. Discretionary Income, sebagai akibat meningkatnya jumlah uang yang kalau dibelanjakan tidak akan mengganggu keperluan keluarga sehari-hari.

e. Paid Vacation, atau dana tunjangan yang diberikan oleh perusahaan atau instansi berupa uang cuti kepada karyawannya yang digunakan untuk keperluan berlibur.

f. Status and Prestige Motivation, motivasi ini bersifat sangat emosional karena mendorong seseorang dalam menjaga prestisenya. Jadi perjalanan wisata yang dilakukan hanya karena termotivasi untuk menjaga status dan prestise saja.

Sementara itu Hadinoto (dalam Sunaryo: 2013) menerangkan bahwa industri pariwisata adalah suatu susunan organisasi baik pemerintah maupun swasta yang terkait dalam pengembangan, produksi dan pemasaran produk suatu layanan untuk memenuhi kebutuhan dari orang yang sedang berpergian. Sedangkan usaha pariwisata didefinisikan sebagai kegiatan yang bertujuan menyelenggarakan jasa pariwisata atau menyediakan atau mengusahakan objek dan daya tarik wisata, usaha barang pariwisata, dan usaha lain yang terkait 
bidang tersebut. Usaha tersebut tentunya akan membutuhkan banyak tenaga kerja yang selanjutnya memberikan tambahan bagi perekonomian di sekitarnya.

\section{METODE}

Penelitian ini menggunakan analisis statistik. Pengumpulan data dilakukan melalui penyebaran kuesioner dan wawancara. Sampel penelitian adalah 30 orang pelaku usaha wisata dan 30 orang masyarakat Kota Batu,

\section{HASIL PENELITIAN}

Aspek Government Power dari Responden Pelaku Usaha Wisata

Tabel 1. Aspek Government Power dari Responden Pelaku Usaha Wisata

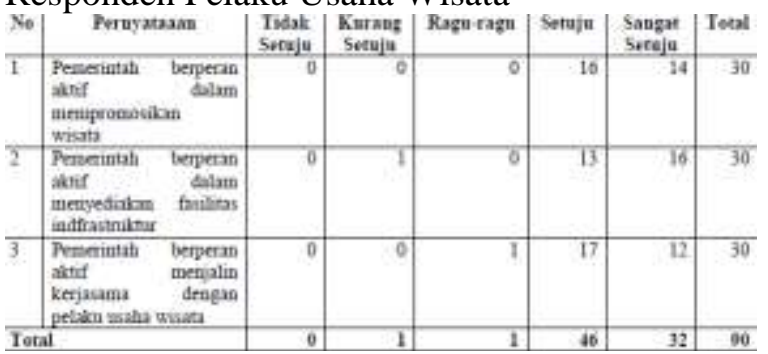

Sumber : data diolah

Berdasar tabel di atas, pada masingmasing sub aspek Government Power , mayoritas responden pelaku usaha wisata menyatakan setuju bahwa pemerintah Kota Batu aktif mempromosikan wisata Kota Batu sebesar 16 orang (53\%), mayoritas responden pelaku usaha wisata menyatakan sangat setuju pemerintah aktif dalam menyediakan fasilitas infrasruktur sebesar 16 orang (53\%), dan mayoritas responden pelaku usaha wisata menyatakan setuju pemerintah aktif menjalin kerjasama dengan pelaku usaha wisata sebesar 17 orang (57\%). Oleh karena itu, secara keseluruhan dapat disimpulkan bahwa pada semua item aspek power dependen mayoritas responden pelaku usaha menjawab setuju. Hal ini berarti pelaku usaha wisata menganggap pemerintah Kota Batu berperan aktif dalam usaha mengembangkan industri pariwisata di Kota Batu.

\section{Aspek Government Power dari Responden Masyarakat}

Tabel 2. Aspek Government Power dari Responden Masyarakat

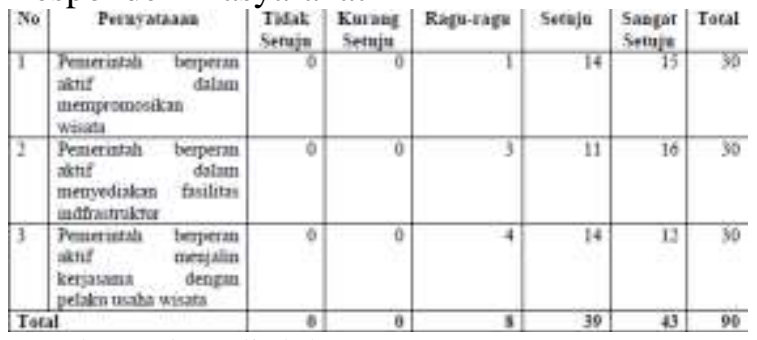

Sumber : data diolah

Berdasar tabel di atas, pada masingmasing sub aspek Government Power , mayoritas responden masyarakat menyatakan sangat setuju bahwa pemerintah Kota Batu aktif mempromosikan wisata Kota Batu sebesar 15 orang (50\%), mayoritas responden masyarakat menyatakan sangat setuju pemerintah aktif dalam menyediakan fasilitas infrasruktur sebesar 16 orang (53\%), dan mayoritas masyarakat wisata menyatakan setuju pemerintah aktif menjalin kerjasama dengan pelaku usaha wisata sebesar 14 orang (47\%). Oleh karena itu, secara keseluruhan dapat disimpulkan bahwa pada semua item aspek Government Power mayoritas responden masyarakat menjawab sangat setuju. Hal ini berarti msayarakat menganggap pemerintah Kota Batu berperan aktif dalam usaha mengembangkan industri pariwisata di Kota Batu.

\section{Aspek Perkembangan Industri Pariwisata Dari Responden Pelaku Usaha Wisata}

Tabel 3. Aspek Perkembangan Industri Pariwisata dari Responden Pelaku Usaha Wisata

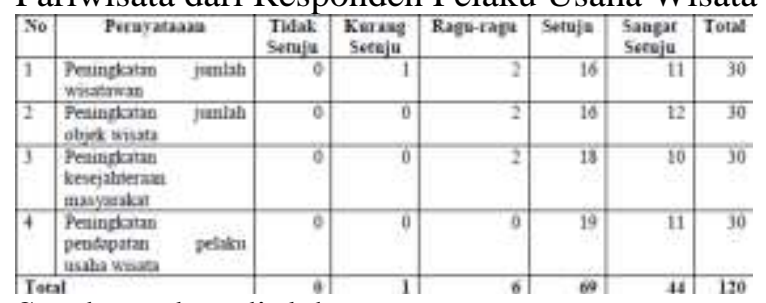

Sumber : data diolah

Berdasar tabel di atas, pada masingmasing sub aspek perkembangan industri pariwisata, mayoritas responden pelaku usaha wisata menyatakan setuju bahwa 
terdapat peningkatan jumlah wisatawan di Kota Batu sebesar 16 orang (53\%), mayoritas responden pelaku usaha wisata menyatakan setuju terdapat peningkatan jumlah objek wisata di Kota Batu sebesar 16 orang $(53 \%)$, mayoritas responden pelaku usaha wisata menyatakan setuju bahwa perkembangan wisata berdampak terhadap peningkatan kesejahteraan masyarakat di Kota Batu sebesar 18 orang (60\%), dan mayoritas responden pelaku usaha wisata menyatakan setuju bahwa perkembangan wisata berdampak terhadap peningkatan peningkatan pendapatan pelaku usaha wisata di Kota Batu sebesar 19 orang (63\%), Oleh karena itu, secara keseluruhan dapat disimpulkan bahwa pada semua item aspek perkembangan industri pariwisata mayoritas responden pelaku usaha menjawab setuju. Hal ini berarti pelaku usaha wisata menganggap perkembangan industri wisata di Kota Batu berdampak bagi bagi pelaku usaha wisata di Kota Batu maupun masyarakat secara umum.

\section{Aspek Perkembangan Industri Pariwisata Dari Responden Masyarakat}

Tabel 4. Aspek Perkembangan Industri Pariwisata dari Responden Masyarakat

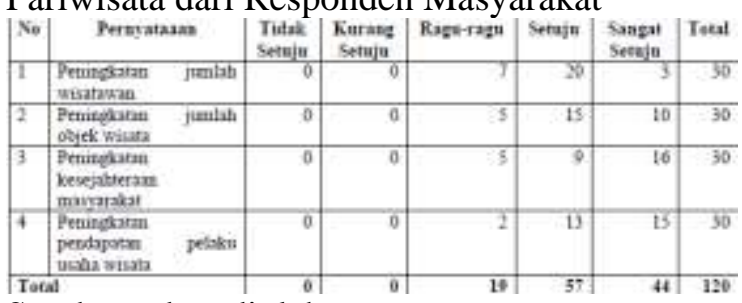

Sumber : data diolah

Berdasar tabel di atas, pada masingmasing sub aspek perkembangan industri pariwisata, mayoritas responden masyarakat menyatakan setuju bahwa terdapat peningkatan jumlah wisatawan di Kota Batu sebesar 20 orang (67\%), mayoritas responden masyarakat menyatakan setuju terdapat peningkatan jumlah objek wisata di Kota Batu sebesar 15 orang (50\%), mayoritas responden masyarakat wisata menyatakan sangat setuju bahwa perkembangan wisata berdampak terhadap peningkatan kesejahteraan masyarakat di
Kota Batu sebesar 16 orang (53\%), dan mayoritas responden masyarakat menyatakan sangat setuju bahwa perkembangan wisata berdampak terhadap peningkatan peningkatan pendapatan pelaku usaha wisata di Kota Batu sebesar 15 orang (50\%), Oleh karena itu, secara keseluruhan dapat disimpulkan bahwa pada semua item aspek perkembangan industri pariwisata mayoritas responden masyarakat menjawab setuju. Hal ini berarti masyarakat menganggap perkembangan industri wisata di Kota Batu berdampak bagi bagi pelaku usaha wisata di Kota Batu maupun masyarakat secara umum.

Tabel 5. Analisa Statistik

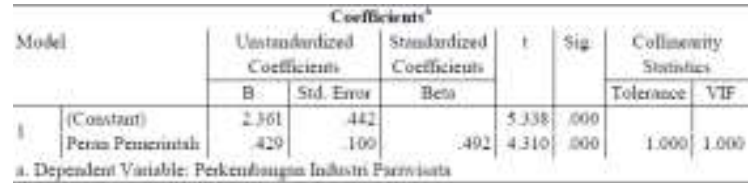

Sumber : data diolah

Dari hasil analisa statistik aspek Government Power signifikan berpengaruh terhadap perkembangan industri pariwisata $(\operatorname{sig} \mathrm{t}=0,00)$. Hal ini berarti bahwa pemerintah mempunyai peran penting dalam mengembangan industri pariwisata di Kota Batu

\section{Pembahasan}

Dari hasil analisa di atas, terlihat bahwa kekuatan/kekuasaan pemerintah sangat diperlukan dalam membangun suatu industri pariwisata. Hal ini sesuai dengan pendapat Emerson (1996) yang menyatakan kekuatan/ kekuasaan dalam konteks hubungan antar entitas organisasi menurut Emerson (1962) adalah kemampuan satu pihak mempengaruhi pihak lain untuk mentaati ketentuan dan atau merubah suatu kondisi yang tidak mendukung keberlangsungan suatu hubungan.

Pada tahun 2012, total wisatawan yang berkunjung ke Kota Batu mencapai 1.603.441 wisatawan. Pada tahun 2013 meningkat mencapai 1.881 .446 wisatawan dan 2.089.022 wisatawan pada tahun 2014 (Kota Batu Dalam Angka 2015). Angka itu naik drastis jika dibandingkan pada tahun 2007 saat kondisi wisata Kota Batu terpuruk 
akibat luapan lumpur Lapindo, dimana jumlah kunjungan wisata kurang dari 1 juta orang. Angka itu naik drastis jika dibandingkan pada tahun 2007 dimana jumlah kunjungan wisata kurang dari 1 juta orang. Bahkan pada APBD 2016, Pemkot Batu memasang target pendapatan $\mathrm{Rp} 1$ triliun dimana $80 \%$ berasal dari sektor pariwisata. Kemajuan industri pariwisata di Kota Batu tidak terlepas dari $p$ eran pemerintah yang pada saat industri pariwisata"terpuruk" menggunakan "power" nya untuk memaksa para investor bertahan di Kota Batu. Pemerintah merayu para pengusaha maupun investor agar tetap mempertahankan tempat usaha mereka. Pemerintah juga mulai membuat berbagai kegiatan yang mampu menyedot kunjungan wisata seperti Festival Budaya Jawa Timur, Batu Night Race, Batu Flower Festival, Festival Paralayang Nasional dan lain-lain. Pemerintah juga jaminan keamanan kepada investor untuk menginvestasikan modalnya. Dalam perkembangannya, kepercayaan investor mulai meningkat dan investor mulai membidik Kota Baru sebagai wisata edukasi. Sasarannya adalah pelajar maupun keluarga. Wisata buatan berbasis edukasi tersebut mampu membuat Kota Batu kembali dikenal luas. Melihat jumlah kunjungan wisata naik, pemerintah juga mulai mengemas Alun-Alun Kota Batu sebagai tempat wisata.

\section{KESIMPULAN DAN SARAN}

Dari hasil analisa statistik aspek Government Power signifikan berpengaruh terhadap perkembangan industri pariwisata $(\operatorname{sig} \mathrm{t}=0,00)$. Hal ini berarti bahwa peran pemerintah mempunyai pengaruh dalam mengembangan industri pariwisata di Kota Batu

Untuk mempertahankan dan meningkatkan wisata Kota Batu, pemerintah harus mampu menciptakan sinergi dengan pelaku usaha wisata dan masyarakat. Pemerintah harus lebih giat lagi mendorong kerjasama antara pelaku usaha wisata dan menggerakkan masyarakat untuk aktif dalam kegiatan promosi seperti pengenalan budaya lokal kepada wisatawan

\section{DAFTAR PUSTAKA}

Anderson, Erin, and Barton, Weitz. 1992. "The Use of Pledges to Build and Sustain Commitment in distribution Channels". Journal of Marketing Research. Vol.XXIX (Feb),pp.18-34.

Alimuddin Rizal Riva'i, 2009, Kekuatan Memaksa Dalam Pemasaran Relasional Dan Dampaknya Pada Strategic Marketing Outcomes (Studi Empirik Pada Industri Pariwisata Di Indonesia), Univ. Diponegoro, Semarang

Berry, Leonard.L. 1983. "Relationship Marketing": in Emerging Persfective onServices Marketing. American Marketing Association. pp 25-28.

Bucklin, Louis P, and Sanjit Sengupta. 1993. "Organizing Successful Co- Marketing Alliances." Journal of Marketing. " Vol.57 (2), pp.32-46.

Dahl, Robert.A. 1957. "The Concept of Power". Journal of Behavioral Science. Vol.2 (Juli), pp.201-215.

Doherty, A.M. and Quinn. B. 1999. "International retail franchising: an agency Theory perspective". International Journal of Retail \& DistributionManagement. Vol. 27 No. 6, pp. 224-66.

Egan, John. 2001. Relationship Marketing: Exploring Relationship Strategies in Marketing. 1th ed. Pearson Education Limited, England.

Emerson, Richard.M. 1962. "PowerDependence Relations". American Sociological Review. 27 (Feb), pp.3141

Hennig-Thurau 2000. "Relationship Quality and Customer Retention through Strategi Communication of Customer Skills." Journal of Marketing Management. Vol.16 (1/3), pp.55-79.

Hennig-Thurau,Kevin.P. Gwinner, and Dwayne D. Gremler. 2002. "Understanding Relationship Marketing Outcomes: An Integration of Relational Benefits and Relationship Quality." Journal of Service Research, February. pp.230-247. 
Hermans, and Kevin J.Shanahan. 2003.

Testing the commitment-Trust Theory

of Relationship Marketing in Situations of Hight and Low Coercive

Power,Forcoming in the Proceding of the American Marketing AssociationSummer Educator's Conference (AMA), Chicago, IL, Agustus.

Hoffman,Nicole.P. 2000. "An Examination of the Sustainable Competitive Advantage, Concept: Past, Present, and Future. Academy of Marketing Science Review. Vol- 4.

Morgan, Rob.M, and Shelby D. Hunt. 1994. "The Commitment-Trust Theory ofRelationshi Marketing," Journal of Marketing. Vol.58 (July), pp.20-38.

Palmer,1996. "Relationship Marketing: a universal paradigm or management pad?". The Learning Organisation. Vol.3(3),pp.18-25. . 1998. "Principles of Service Marketing". Ed.1.London, Kogan Page.

.2000. "Co-operation and Competition: a Darwinian synthesis of relationship marketing". European Journal of Marketing. Vol.34 (5/6), 687-704.

Sunaryo, Bambang. 2013. Kebijakan Pembangunan Destinasi Pariwisata: Konsep dan Aplikasinya di Indonesia. Yogyakarta: Gava Media

Tarigan, Robinson. 2005. Ekonomi Regional: Teori dan Aplikasi. Edisi Revisi. Jakarta: PT Bumi Aksara

Wahab, Salah. 2003. Manajemen Kepariwisataan. Ed.4. (Frans Gromang), Jakarta: PT. Pradnya Paramita

Yoeti, Oka A. 2008. Ekonomi Pariwisata: Introduksi, Informasi dan Aplikasi. Jakarta: PT Kompas Media Nusantara 